on the very water-beetles that were among the chief of Finkler's corpora vilia) come forward with a detailed and documented confession of their failure, after persistent attempts, to confirm the simplest of Finkler's results. They followed carefully his instructions as to procedure, and only after this failed did they try to refine upon his technique. The severed heads certainly adhered to the bodies on which they had been placed, cemented, in fact, by the coagulated blood which dried to a chitin-like hardness, but in no case did the insects survive longer than others in which, after decapitation, the wounds were stanched with a little melted wax; in no case did the chimæras behave differently from the headless trunks ; in no case did stimulation of the head produce reflex movement in the body or its limbs. Microscope sections showed no attempt at regeneration or union of the tissues, but instead, a progressive necrosis, leading more or less quickly to the death, first of the head and later of the trunk. These results followed, even in cases of replantation where the severed head was replaced at once on the body from which it had been detached.

Dr. Finkler may of course be able to point out to us where the German experimenters have gone wrong, but there seems to be a familiar ring in their complaint that he has ignored requests to produce his chimæras, alive or dead, for investigation by others. He cannot ignore the challenge of their final words: "Die Wissenschaft hat angesichts der allen Erfahrungen widersprechenden Angaben des Wiener Autors keine Veranlassung, sich weiter mit ihm und seine Schriften zu beschäftigen."

British Museum (Natural History),

South Kensington, S.W.7.

\section{The Origin of Ores.}

REFERRING to the very kind review by Prof. $H$. Louis of my book "The Geology of the Metalliferous Deposits " in NATURE of June 7, p. 8I2, I wish to direct attention to one point. Prof. Louis quotes the following sentence: "It would perhaps be too much to say in the present state of our knowledge that all primary ore-deposits are of igneous origin, but this is a view which may very likely be established as a result of future work." He then goes on to instance the hæmatite deposits of Cumberland as ores which are certainly not of igneous origin. With this, of course, I entirely agree, and I wish to say that my statement was certainly never meant to include them, as may be seen by referring to p. 330 of my book. The emphasis in the sentence quoted is on the word primary, whereas I regard the hæmatites of Cumberland and northern Spain as secondary ores. Should a second edition of the book be called for, steps will be taken to make this point quite clear.

Christ's College, Cambridge.

R. H. Rastall.

\section{Exhibit of Pure Science at the British Empire Exhibition.}

In NATURE of June 21 , p. 896 , there is a reference to the instruments exhibited under my name in the Royal Society's section in the Government Pavilion at the British Empire Exhibition dealing with the measurement of atmospheric pollution. I should like to make it clear that the credit for the original idea underlying the contrast photometer exhibited is due to Mr. L. F. Richardson. It is a development of the method described by him in the Proceedings of the Royal Society, A, vol. 96, 1919. The principle was further elaborated by the Photometric Sub-Committee of the Advisory Committee on Atmospheric Pollution, my share being only that of getting out a workable design and making the experimental instrument. I was fortunate in getting at the first attempt an instrument with remarkable sensitiveness and accuracy, which required practically no alteration and enabled a measure of light obstruction by fog to be obtained.

During the smoke fog in the afternoon of November 26 last in South Kensington, a fairly dense fog containing about $2 \frac{1}{4}$ milligrammes of soot per cubic metre and about 24 , ooo smoke particles per cubic centimetre, the obstruction of light in 50 feet was 46 per cent. In the morning of the same day at II.45 the amount of suspended matter was 3.8 milligrammes per cubic metre and the number of particles 82,000 , the obstruction of light in 50 feet being 75 per cent.

J. S. OWENS.

Advisory Committee on Atmospheric Pollution,

47 Victoria Street, Westminster, London, S.W.I, June 25.

\section{Birds as a Geological Agent.}

ALL along the tops of the cliffs of the Undercliff from Ventnor to Blackgang empty shells of the common limpet are found in large numbers, and it has usually been assumed that their shape has caused them to be blown by the wind from the beach over the cliffs. There are so many of them that I have found it difficult to believe this theory, and on mentioning it to a local naturalist, he has assured me that he has seen rooks and jackdaws pick them up from off the rocks while living, and convey them in their beaks to the trees where they roost and nest and to other places, and after feeding on them, cast away the empty shells. This may account for the mixture of marine shells with land shells in some of the tertiary strata which is sometimes inexplicable.

\section{Holmesdale Road,} EDWARD A. Martin. South Norwood, S.E.

\section{A Substitute for the McLeod Gauge.}

THE letter on the McLeod gauge appearing in NATURE of November 3 has only just come to my notice.

There may be gauges which, having been compared with a McLeod gauge, will give equivalent readings, but there is no substitute for the McLeod gauge in its perfect measurement of low pressures, expressed in height of mercury column.

If the McLeod gauge is used with proper knowledge, it will indicate aqueous vapour as well as permanent gases. When the gauge is so proportioned that the difference of the height of the mercury in the capillary columns is less than $4 \mathrm{~mm}$. and the temperature is above $0^{\circ} \mathrm{C}$., any aqueous moisture present will act as a permanent gas and will give a true reading of the pressure absolute.

Henry A. Fleuss.

47 Albert Road, Caversham, Reading, June 16.

\section{Ceremonial Banquets.}

I HAVE recently received an invitation to forward a cheque for two guineas, as a fee for attending the banquet in connexion with the Kelvin Centenary. It is difficult to understand why the memory of a man of simple habits should call for such a sumptuous repast, or why scientific workers of frugal habits should be excluded from such a celebration. In view of the growing tendency to limit functions such as these to men of means rather than to men of science, it is surely time to make a protest against the methods of organisation which lead to so undesirable a result. F.R.S.

$$
\text { No. } 285.3 \text {, vOL. I I } 4 \text { ] }
$$

